\title{
Assembly processes of moss and lichen community with snow melting at the coastal region of the Barton Peninsula, maritime Antarctic
}

Seok Cheol Kim¹, Jun Seok Kim, Bo Ram Hong ${ }^{1}$, Soon Gyu Hong², Ji Hee Kim² and Kyu Song Lee ${ }^{1 *}$

\begin{abstract}
Background: In this article, it was analyzed how snow melting affects the assembly of lichen and moss communities in a small area of the coastal region of Barton Peninsula, which is in maritime Antarctic. In the small area, even though there is a huge gap of difference of the environment between the snow-filled area and snow-melt one, the latter did not have distinctive environmental gradients.

Results: Depending on the snow melting time, coverage and species diversity of lichens and mosses tend to increase remarkably. For species with significant changes depending on the snow-covered period, there are Andreaea regularis, crustose lichens, Placopsis contortuplicata, Usnea aurantiaco-atra, and snow algae. In this area, the process of vegetation assembly process has shown the directional development in the order of snow algae $\rightarrow$ crustose, lichen sub-formation $\rightarrow$ fruticose lichen, moss cushion sub-formation (Andreaea sociation) $\rightarrow$ fruticose lichen, and moss cushion sub-formation (Usnea sociation), according to the order of snow melting. These directional development stages are shown in gradual change in small area with the snow melting phenomena. However, in the snow-free area, where water is sufficiently supplied, it is expected that moss carpet sub-formation (Sanionia sociation) will be developed. Vegetation development in the small area with the snow melting phenomena, depending on differences of resistance on snow kill and moisture settled by species in according to the time of snow melting, tolerance model to form community is followed.
\end{abstract}

Conclusions: The research results explain the development of vegetation in the Antarctic tundra and its spatial distribution according to the period for growth of lichens and mosses in the summer time by differences of snow melting in the small area. In the future, if research for the community development process in a large scale will be done, it will be helpful to figure out temporal and spatial dynamic of vegetation in the Antarctic tundra where snow and glaciers melt rapidly due to climatic warming.

Keywords: Antarctic tundra, Community assembly, Snow melting, Barton Peninsula, Maritime Antarctic, Lichens, Mosses

\footnotetext{
* Correspondence: leeks84@gwnu.ac.kr

'Department of Biology, Gangneung-Wonju National University, Gangneung

25457, South Korea

Full list of author information is available at the end of the article
} 


\section{Background}

Global warming may bring changes in environmental conditions in diverse geographical areas, and it will in turn bring changes in structures and functions of ecosystems (Grimm et al. 2013). The West Antarctic area, including the Antarctic Peninsula and South Shetland Islands, is one of the fastest warming areas in the world (Oppenheimer 1998). The Antarctic ecosystem may be affected at large by a small environmental change (Lewis Smith 1984, Longton 1988, Lewis Smith 1990, Kennedy 1995). The studies about responses of the Antarctic ecosystem and species on climatic changes are helpful to understand global changes according to climatic warming (Convey et al. 2009, Turner et al. 2009, Convey 2010).

The literatures about the development of vegetation after glacier retreat are mostly about comparison of changes of environment and biotic community in regions with different deglaciation history. For the Arctic region, there are many studies to trace the changes of ecosystems after glacier retreat (Jones and Henry 2003, Favero-Longo et al. 2012). Vegetation succession in the Arctic region tends to be forward with direction from pioneer to climax. However, non-directional vegetation succession was also reported in polar desert with harsh environment (Jones and Henry 2003). Favero-Longo et al. (2012) demonstrated that vegetation succession according to glacier retreat in the Signy Island in the maritime Antarctic region are divided into pioneer community, immature community, and climax and that the driving force to determine vegetation in the Antarctic region is the duration after glacier retreat. In the process of vegetation succession in the Arctic region, many vascular plants participate in each stage. However, in the Antarctic region, there are only two vascular plants: Deschampsia antarctica and Colobanthus quitensis (Parnikoza et al. 2012). Therefore, lichens and mosses are expected to play main roles in vegetation succession as dominant species in the Antarctic region. In addition, the development of coastal ecosystem in the Antarctic region is largely affected by maritime ecosystem mediated by animals, and with very slow speed in soil forming, ground consisting of rocks or stones is very widely distributed (Parnikoza et al. 2012). Accordingly, there may be a possibility of that vegetation succession, and its driving force in the Antarctic region is different from that in the Arctic region. And it may follow a vegetation succession model different from the facilitation model that the species in the early stage of vegetation succession known in the Arctic region promote settlement and development of the species in the later stage.

Most of the Antarctic regions are covered with permanent snow and glacier, and then distribution of vegetation is limited within the coastal region in which snow melts in summer time. Recently, vascular plants, D. antarctica and C. quitensis, have spread in the maritime Antarctic region (Kim et al. 2007, Favero-Longo et al. 2012, Korea's Ministry of Environment 2014). However, dominant vegetations in this region are lichens and mosses (Kim et al. 2007, Choi et al. 2015). Accordingly, it is important to figure out the factors in determining the spatial distribution of lichen and moss communities in the maritime Antarctic region (Tilman and Pacala 1993, Tang et al. 2013). The factors closely related to the spatial distribution of lichens and mosses in the maritime Antarctic region include snow melting time, continuity of exposure, distribution of available water, and distribution of animalproviding nutrient salts (Kim et al. 2007, Favero-Longo et al. 2012, Parnikoza et al. 2012, Kim et al. 2013, Choi et al. 2015). Because of recent global warming, glacier melting areas in the maritime Antarctic region have been rapidly increasing (Convey et al. 2009, Parnikoza et al. 2012). Even in snow-melt areas, these are increasing in both exposed areas by snow melting in the summer and those with longer exposure. However, in the maritime Antarctic region, compared to the Antarctica, the summer climate is very fluctuating and annual changes of snowing amount are also huge. So there are many regions frequently fluctuating in the exposed area, its continuity, and system of water flow by snow melting (Shin et al. 2014). In the maritime Antarctic region, like climatic changes, climatic fluctuation may have very significant influences on the distribution of species (Olsen et al. 1993, Shin et al. 2014). Life's responses to climatic changes and fluctuation are related to spatial dimensions (Lewis Smith 1972, Longton 1988). Climatic change affects the distribution of species and development of the ecosystem in a broader spatial scale while climatic fluctuation influences the distribution and vitality of the species in small- or micro-scale (Bisigato et al. 2009). The studies about life's response on climatic fluctuation in the Antarctic region are very critical in the prediction of the distribution of species in micro-scale. In particular, studies about climatic fluctuation in various scales in individual unit, population, community, and ecosystem and various spatial scales of small, mid-level, local, and regional level may help to understand distribution, origin, succession, and evolution of life in the Antarctic region (Reynolds and Wu 1999, Crawley and Harral 2001, Gillson 2004, Bisigato et al. 2009). In addition, these studies may contribute to predict changes in the Antarctic ecosystem to upcoming climatic changes and irregular climatic fluctuation.

A small area with complex topography in the maritime Antarctic region offers variety in the annual snow coverage continuity, snow depth, and water supply amount depending on climatic fluctuation and has environmental gradients with consistent direction (Kim et al. 2007, Favero-Longo et al. 2012). Even in the same year, depending on micro-topography, there may be different 
gradients in snow melting time, period of snow cover, and water supply capacity (Choi 2015; Choi et al. 2015). Therefore, small areas with complex topography are a proper site for experiment to study the establishment of vegetation according to the extension of progressively exposed areas, their vegetation succession, and responses of biotic communities to climatic fluctuation.

This study aims to figure out factors in determining the spatial distribution and changes of vegetation with snow melting at small spatial scale and find out the assembly processes of cryptogam community in this area.

\section{Methods}

\section{The research area}

King George Island is the largest island in the South Shetland Islands and is located in the scope from $61^{\circ}$ $50^{\prime} \mathrm{S}$ to $62^{\circ} 15^{\prime} \mathrm{S}$ in latitude and from $57^{\circ} 30^{\prime} \mathrm{W}$ to $59^{\circ} 01^{\prime}$ in longitude. The island spreads from southwest to northeast in a long line. Its length is $54 \mathrm{~km}$ and its width is $40 \mathrm{~km}$. Most of the ground areas are covered with glaciers, and in its coastal region, limited snow-free areas are exposed. The climate there is oceanic and wet and milder than the continental Antarctica. In King George Island, glacier retreat started about 6000 years ago in the Holocene, and its climatic optimum was between 4000 before Christ (B.C.) and 3000 B.C. (Björck et al. 1991, Yoon et al. 2000). Barton Peninsula is located in the southwestern part of King George Island, and it has about $4 \times 3 \mathrm{~km}$ ground snow-free area in the summer. The central part of Barton Peninsula has altitudes ranging from 90 to $180 \mathrm{~m}$, with smooth slope, but its topography is very complex. The annual average temperature there ranges in $-1.8 \sim 1.6{ }^{\circ} \mathrm{C}$, and the average temperature in January is $1.9{ }^{\circ} \mathrm{C}$. The annual relative humidity is $89 \%$, and the annual precipitation is $437.6 \mathrm{~mm}$. The average wind speed is $7.9 \mathrm{~m} / \mathrm{s}$, and the main wind directions are northwest and southwest winds (Lee et al. 1997, Chung et al. 2004). For the flora in Barton Peninsula, there are two vascular plants of $D$. antarctica and $C$. quitensis. In addition, 33 moss species and 68 lichen species were reported (Korea's Ministry of Environment 2014).

The small-scale area where the research was conducted is located in the southwest coastal area in Barton Peninsula where King Sejong Station is established. The geological location is $62^{\circ} 13^{\prime} 36^{\prime \prime} \mathrm{S}, 58^{\circ} 47^{\prime} 07^{\prime \prime} \mathrm{W}$ while the area's altitude ranges between 30 and $40 \mathrm{~m}$ comparatively smooth. The peripherical topography is surrounded by low hills. In this study, in order to investigate the changes of vegetation by a single factor of snow melting speed, the topography is connected from ridge to valley (Fig. 1). In order to investigate the snow cover duration, snow cover borderline was drawn by four times from January 14 to February 18, 2015 (Fig. 2). In the figure, the thick-lined curve indicates the boundary of the snowcovered areas checked in each investigation time. The dark gray part is the snow-free area in the earlier time in the investigation (before 14 January); lichens such as Usnea sp. were dominant while the white part shows snow-covered areas until the final investigation (after 18 February).

\section{Study period}

This research was conducted for about 7 weeks from January 14 to February 28, 2015. Plots were installed, and in order to measure snow melting speed, from January 14 to February 28, 2015, with four sessions, outer boundaries of snow-covered areas were investigated. The vegetation investigation was conducted on February 18, 2015, when snow was melted in the maximum scale.

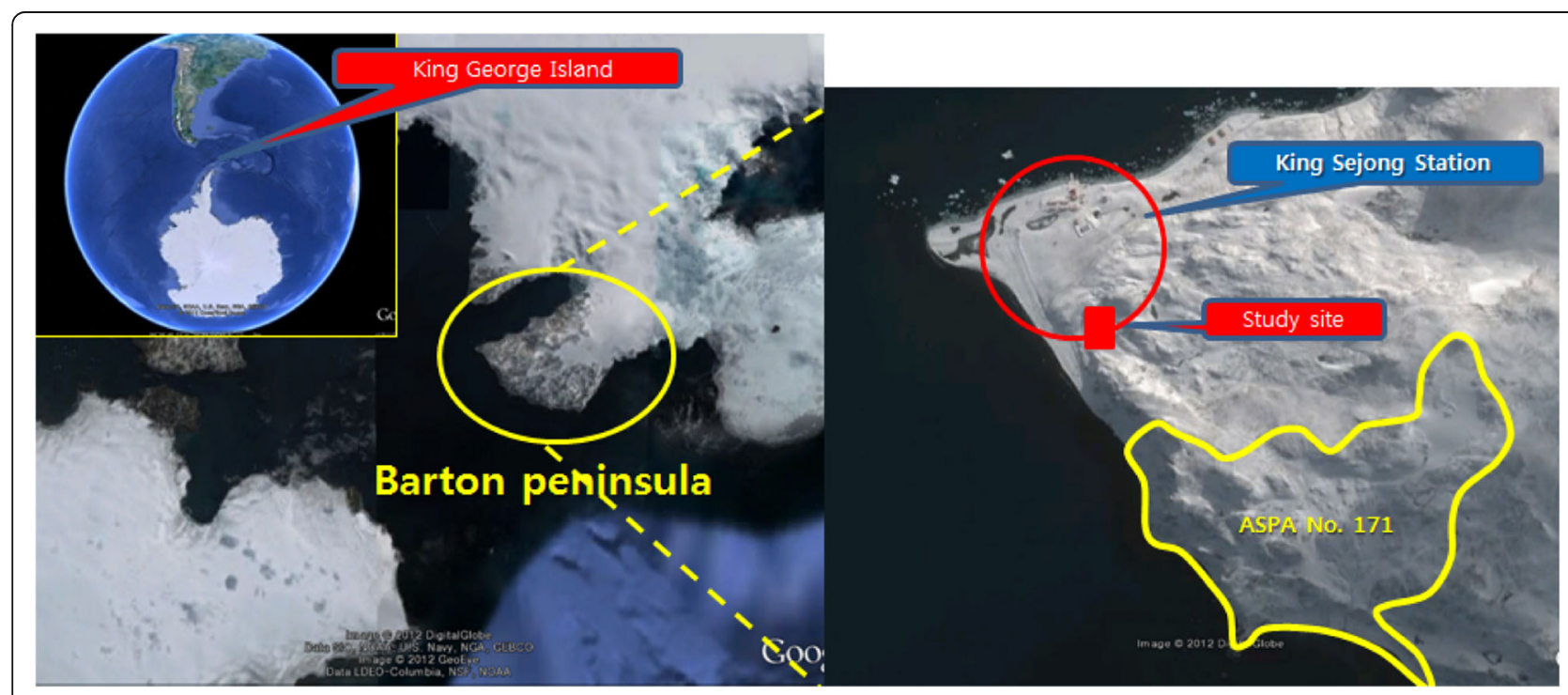

Fig. 1 Map showing the study site 


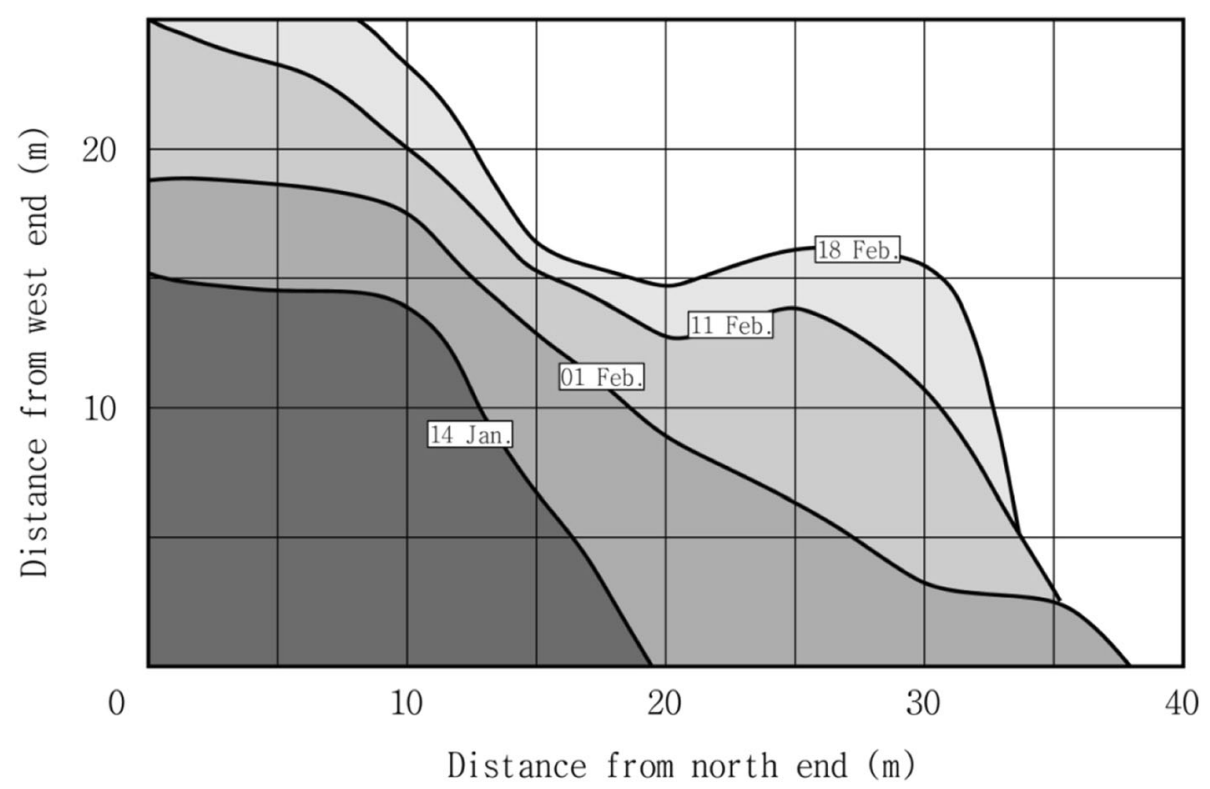

Fig. 2 Map showing the retreat timing of snow cover in the study area

\section{Installation of plots}

After selecting smooth-tilted areas where snow melting changes seem to be distinctive according to time due to the connection from ridge to valley, lattice plots with width of $40 \mathrm{~m}$ and length $25 \mathrm{~m}$ were installed. For plots, 54 small lattices with the size of $5 \mathrm{~m} \times 5 \mathrm{~m}$ were divided, and then small plots for investigation with $0.5 \mathrm{~m} \times 0.5 \mathrm{~m}$ were installed. In each plots, environmental factors and coverage of lichens and mosses were recorded.

\section{Measures of environmental factors}

For altitude and topography in plots, they were measured with relative altitude by using auto-level in each micro-lattice. Snow depth was measured by using a steel bar with $1 \mathrm{~cm}$ in diameter. The investigated data were transferred into an isopleth in 2D by using geographical statistic analysis package GS+ (Fig. 3). For locational factors, sea level, aspect, micro-topography direction, slope, micro-topography, size of substrate particles, and

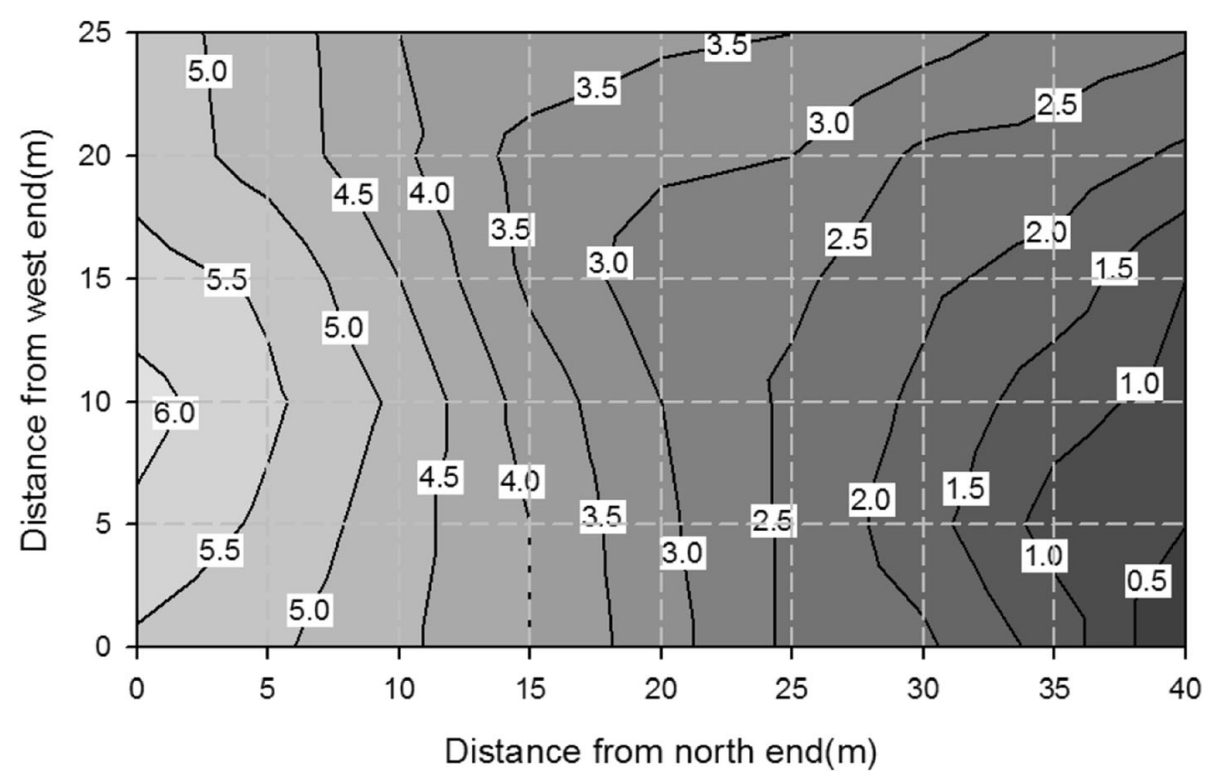

Fig. 3 Topographic map of the study area. Each contour line means relative altitude (m) 
soil moisture gradients were measured. They were classified by several categories with the criteria in Table 1 .

\section{Collection and analysis of vegetation data}

In the $0.5 \mathrm{~m} \times 0.5 \mathrm{~m}$ plots installed in each investigation point, height and coverage of vegetation were measured and then pictures of vegetation in the plots were taken and the coverage classes for each species were assessed indoor. The images of vegetation data were acquired with high-resolution digital camera with $12 \mathrm{MP}$. The classification of vegetation types was done by using dominant species with higher coverage rank. Importance value was calculated by summing relative frequency and relative coverage of each species, and percentage of importance value was calculated.

The data acquired from 54 locations were used for the analysis by a vector table consisting of vegetation data and environmental factors of the investigated points by using MS Excel 2010 (Microsoft, Raymond, WA, USA). In each plot, indices were calculated by classifying into lichens, mosses, and the total taxa. In order to figure out influences of snow melting on the diversity of cryptogam communities, various indices were calculated. Species richness (number of species that appeared in each plots), dominance (C, Simpson 1949), evenness (J, Pielou 1969), and Shannon-Weaver index $\left(H^{\prime}\right.$, Krohne 2001) for species diversity were calculated using the following equations:

$$
\begin{aligned}
& C=\sum(P i)^{2} \\
& H^{\prime}=-\sum(P i \ln P i) \\
& J=H^{\prime} / \ln (S)
\end{aligned}
$$

Here, $S$ is the total number of species in each plot and $P i$ is relative important value of $I$ species (Krohne 2001).
Statistical analysis was conducted using SYSTAT ver. 12.0 (SYSTAT Software Inc., San Jose, CA, USA). For comparison of means among types of communities depending on snow melting time, one-way analysis of variance (ANOVA) was conducted, while Turkey's test was done for post hoc test. Canonical correlation analysis (CCA) ordinations were performed using CANOCO ver. 4.5 in order to analyze the main factors affecting the spatial distribution of the main species (Ter Braak and Šmilauer 2002).

\section{Results}

Does snow melting drive the environmental gradient?

In order to analyze how topographic factors are different in the different locations in snow-covered period and if there is a difference of moisture gradient, according to snow-covered period in the summer, five vegetation types were classified as follows: always snow-free area during summer (section 0); snow-covered area for 2 weeks during summer (section 2); snow-covered area for 4 weeks during summer (section 4); snow-covered area for 5 weeks during summer (section 5); and always snow-covered area during summer (section 6). Environmental factors among classified vegetation types according to snow-covered time are summarized in Table 2. Always exposed area during investigated period and snow-covered area for 2 weeks were very different in environmental factors. Always ground-exposed area during summer is located in the tilted area with higher altitude and smooth slope. For substrate particle size, always snow-free area during summer (pebble) had smaller one than other areas (cobble-pebble). The slope direction in the snow-free area during summer was southeast while that in the always snow-covered area was valley part in southwest slope. Relatively, differences of locational environmental factors among locations with

\begin{tabular}{|c|c|c|c|c|c|c|c|c|c|c|}
\hline \multirow{2}{*}{$\begin{array}{l}\text { Environmental } \\
\text { variables }\end{array}$} & \multicolumn{10}{|l|}{ Category } \\
\hline & 1 & 2 & 3 & 4 & 5 & 6 & 7 & 8 & 9 & 10 \\
\hline $\begin{array}{l}\text { Microaspect } \\
\text { (degrees) }\end{array}$ & $0 \sim 22.5,337.5 \sim 360.0$ & $22.5 \sim 67.5$ & $67.5 \sim 112.5$ & $112.5 \sim 157.5$ & $157.5 \sim 202.5$ & $202.5 \sim 247.5$ & $247.5 \sim 292.5$ & $292.5 \sim 337.5$ & - & - \\
\hline Microaspect & $\mathrm{N}$ & $\mathrm{NE}$ & $E$ & SE & S & SW & W & NW & - & - \\
\hline $\begin{array}{l}\text { Inclination } \\
\text { (degrees) }\end{array}$ & $0 \sim 5$ & $5 \sim 10$ & $10 \sim 15$ & $15 \sim 20$ & $20 \sim 25$ & $25 \sim 30$ & $30 \sim 35$ & $>35$ & - & - \\
\hline Topology & Summit & Ridge & Upper slope & Middle slope & Lower slope & Arid valley & Stream flow & Pond or wet land & - & - \\
\hline Microtopolgy & Upper slope & Middle slope & Lower slope & Arid valley & - & - & - & - & - & - \\
\hline Substrate & Rock & Boulder & Boulder-cobble & Cobble & Cobble-pebble & Pebble & Pebble-fine grain & Coastal sand & Fine grain & Humus \\
\hline $\begin{array}{l}\text { Wind } \\
\text { exposure }\end{array}$ & Very strong & Strong & Moderate & Weak & Very weak & - & - & - & - & - \\
\hline Moisture & Very arid & Arid & Moderate & Slightly wet & Wet & Very wet & Snow & & & \\
\hline $\begin{array}{l}\text { Snow cover } \\
\text { duration (week) }\end{array}$ & 0 & 2 & 4 & 5 & $>6$ & - & - & - & - & - \\
\hline
\end{tabular}
different snow melting times in the southwest region were

Table 1 Criteria for classification categories of the environmental variables 
Table 2 Comparison of environmental variables among vegetation types classified with snow cover duration (week)

\begin{tabular}{|c|c|c|c|c|c|c|c|}
\hline \multirow[t]{2}{*}{ Properties } & \multicolumn{5}{|c|}{ Snow cover duration (week) } & \multirow[t]{2}{*}{ F ratio } & \multirow[t]{2}{*}{$P$} \\
\hline & 0 & 2 & 4 & 5 & 6 & & \\
\hline Number of samples $(n)$ & 12 & 9 & 7 & 5 & 21 & 54 & 54 \\
\hline Altitude (m) & $36.3 \pm 0.2 \mathrm{a}$ & $34.3 \pm 0.4 b$ & $34.4 \pm 0.5 b$ & $35.0 \pm 0.6 \mathrm{ab}$ & $33.5 \pm 0.3 b$ & 11.556 & 0.000 \\
\hline Aspect (degrees) & $4.8 \pm 0.2 \mathrm{a}$ & $4.6 \pm 0.3 a$ & $4.6 \pm 0.5 a$ & $4.8 \pm 0.2 \mathrm{a}$ & $6.0 \pm 0.1 b$ & 10.883 & 0.000 \\
\hline Inclination (degrees) & $2.3 \pm 0.1 \mathrm{a}$ & $3.2 \pm 0.4 b$ & $2.4 \pm 0.3 \mathrm{ab}$ & $2.4 \pm 0.4 \mathrm{ab}$ & $2.7 \pm 0.1 \mathrm{ab}$ & 2.271 & 0.075 \\
\hline Topology & $5.0 \pm 0.0$ & $5.0 \pm 0.0$ & $5.0 \pm 0.0$ & $5.0 \pm 0.0$ & $5.0 \pm 0.0$ & - & NV \\
\hline Micro-topology & $1.2 \pm 0.1 \mathrm{a}$ & $2.3 \pm 0.2 b$ & $2.3 \pm 0.3 b$ & $3.2 \pm 0.5 b$ & $3.1 \pm 0.2 b$ & 16.345 & 0.000 \\
\hline Substrate & $6.1 \pm 0.2 \mathrm{a}$ & $5.3 \pm 0.2 b$ & $5.3 \pm 0.2 b$ & $5.0 \pm 0.2 b$ & $5.3 \pm 0.1 b$ & 4.392 & 0.004 \\
\hline Moisture & $3.1 \pm 0.1 \mathrm{a}$ & $2.3 \pm 0.2 \mathrm{a}$ & $2.7 \pm 0.2 \mathrm{a}$ & $3.0 \pm 1.0 \mathrm{a}$ & $7.0 \pm 0.0 \mathrm{~b}$ & 107.344 & 0.000 \\
\hline Wind exposure & $3.8 \pm 0.3$ & $4.0 \pm 0.0$ & $4.0 \pm 0.0$ & $4.0 \pm 0.0$ & $4.0 \pm 0.0$ & 0.866 & 0.491 \\
\hline
\end{tabular}

According to Tukey's test, columns are statistically different where they do not share any letter $(P<0.05)$

$N V$ no variation in dependent variable

small. In the coastal lowland in Barton Peninsula, snow melts down from smooth-tilted region with the upper slope, where its altitude is relatively higher to lower slope. However, in small-scale region, it seems not to form distinctive environmental gradients between snow-free locations (Table 2).

\section{The influences of snow melting time on vegetational structure}

In order to check if snow-covered time affects vegetational structure, heights $(\mathrm{cm})$ and coverage $(\%)$ of the entire vegetations and each one among the five different vegetation types in snow melting time were compared. For the section "0" location, always exposed area during summer, the height and coverage of the entire vegetation, lichens, and mosses were $7.9 \mathrm{~cm}$ and $83.3 \%$, $4.0 \mathrm{~cm}$ and $64.3 \%$, and $0.7 \mathrm{~cm}$ and $15.9 \%$, respectively. Compared to this, those in locations snow covered for at least more than 2 weeks (sections $2-5$ ) were $0.5 \sim 0.7 \mathrm{~cm}$ and $24.0 \sim 34.8 \%, 0.5 \sim 0.8 \mathrm{~cm}$ and $24.0 \sim 34.0 \%$, and $0.4 \sim 0.7 \mathrm{~cm}$ and $0.6 \sim 4.6 \%$, respectively, showing a quite big difference with location where snow always melts during summer. In areas snow covered for more than 2 weeks, height and coverage of lichens and mosses tended to become lower as snow-covered time was longer but there was no statistical significance (Table 3).

\section{Influences of snow melting time on species diversity}

In sections $0,2,4,5$, and 6 classified according to the snow melting time, species richness was $9,4,4,5$, and 1 , respectively, showing remarkable high richness in always snow-free area during summer. Section 0, always snowfree area during summer, showed 6 and 3 species in lichens and mosses, respectively, and lichens twice more than mosses. For the maximum species density, in the section 0 where snow always melts during summer, it was the biggest with 7 species $/ 0.25 \mathrm{~m}^{2}$. For species density and diversity indices, they tended to increase as exposed period was longer. The taxon with statistical significance in differences between snow-free locations was lichens. For dominance index of lichens, as snowcovered time was longer, the tendency was also bigger. For dominance index of mosses, it was higher in locations covered with snow for 2-4 weeks (Table 4).

Table 3 Comparison of community structure among vegetation types classified with snow cover duration (week)

\begin{tabular}{|c|c|c|c|c|c|c|c|}
\hline \multirow[t]{2}{*}{ Properties } & \multicolumn{5}{|c|}{ Snow cover duration (week) } & \multirow[t]{2}{*}{ F ratio } & \multirow[t]{2}{*}{$P$} \\
\hline & $\overline{0}$ & 2 & 4 & 5 & 6 & & \\
\hline Number of samples $(n)$ & 12 & 9 & 7 & 5 & 21 & & \\
\hline Total height $(\mathrm{cm})$ & $7.9 \pm 4.3 \mathrm{a}$ & $0.7 \pm 0.2 \mathrm{ab}$ & $0.5 \pm 0.0 \mathrm{ab}$ & $0.5 \pm 0.0 \mathrm{ab}$ & $0.0 \pm 0.0 \mathrm{~b}$ & 2.746 & 0.039 \\
\hline Total coverage (\%) & $83.3 \pm 2.7 \mathrm{a}$ & $34.8 \pm 9.6 b$ & $34.3 \pm 5.9 b$ & $24.0 \pm 11.0 \mathrm{~b}$ & $0.0 \pm 0.0 c$ & 56.828 & 0.000 \\
\hline Lichen height (cm) & $4.0 \pm 0.5 \mathrm{a}$ & $0.8 \pm 0.2 b$ & $0.6 \pm 0.1 b$ & $0.5 \pm 0.0 \mathrm{~b}$ & $0.0 \pm 0.0 \mathrm{~b}$ & 46.837 & 0.000 \\
\hline Lichen coverage (\%) & $64.3 \pm 6.7 \mathrm{a}$ & $34.0 \pm 7.9 \mathrm{~b}$ & $31.9 \pm 6.0 b$ & $24.0 \pm 11.0 \mathrm{bc}$ & $0.0 \pm 0.0 c$ & 27.639 & 0.000 \\
\hline Moss height (cm) & $0.7 \pm 0.2 \mathrm{a}$ & $0.7 \pm 0.1 \mathrm{a}$ & $0.5 \pm 0.0 \mathrm{a}$ & $0.4 \pm 0.2 \mathrm{ab}$ & $0.0 \pm 0.0 \mathrm{~b}$ & 8.637 & 0.000 \\
\hline Moss coverage (\%) & $15.9 \pm 6.4 \mathrm{a}$ & $4.6 \pm 2.2 \mathrm{ab}$ & $4.0 \pm 2.7 \mathrm{ab}$ & $0.6 \pm 0.2 a b$ & $0.0 \pm 0.0 \mathrm{~b}$ & 4.119 & 0.005 \\
\hline Snow algae coverage (\%) & $0.0 \pm 0.0 \mathrm{a}$ & $0.0 \pm 0.0 \mathrm{a}$ & $0.0 \pm 0.0 \mathrm{a}$ & $10.0 \pm 10.0 \mathrm{a}$ & $99.3 \pm 0.7 b$ & 681.016 & 0.000 \\
\hline
\end{tabular}


Table 4 Comparison of diversity indices among vegetation types classified with snow cover duration (week)

\begin{tabular}{|c|c|c|c|c|c|c|c|c|}
\hline \multirow[t]{2}{*}{ Properties } & \multirow[t]{2}{*}{ Taxon } & \multicolumn{5}{|c|}{ Snow cover duration (week) } & \multirow[t]{2}{*}{ F ratio } & \multirow[t]{2}{*}{$P$} \\
\hline & & 0 & 2 & 4 & 5 & 6 & & \\
\hline Number of samples $(n)$ & & 12 & 9 & 7 & 5 & 21 & & \\
\hline \multirow[t]{4}{*}{ Alpha diversity (species richness) } & Total & 9.0 & 4.0 & 4.0 & 5.0 & 1.0 & & \\
\hline & Lichens & 6.0 & 3.0 & 3.0 & 3.0 & 0.0 & & \\
\hline & Mosses & 3.0 & 1.0 & 1.0 & 1.0 & 0.0 & & \\
\hline & Algae & 0.0 & 0.0 & 0.0 & 1.0 & 1.0 & & \\
\hline \multicolumn{2}{|l|}{ Maximum species density (no./0.25 ${ }^{2}$ ) } & 7.0 & 4.0 & 4.0 & 3.0 & 1.0 & & \\
\hline \multirow[t]{3}{*}{ Species density (no./0.25 $\mathrm{m}^{2}$ ) } & Total & $3.7 \pm 0.6 \mathrm{a}$ & $3.2 \pm 0.4 \mathrm{a}$ & $2.7 \pm 0.4 \mathrm{a}$ & $2.0 \pm 0.3 \mathrm{ab}$ & $1.0 \pm 0.0 \mathrm{~b}$ & 14.275 & 0.000 \\
\hline & Lichens & $2.9 \pm 0.4 \mathrm{a}$ & $2.3 \pm 0.3 a b$ & $1.7 \pm 0.4 b$ & $1.4 \pm 0.4 b$ & $0.0 \pm 0.0 c$ & 28.224 & 0.000 \\
\hline & Mosses & $0.8 \pm 0.3 \mathrm{a}$ & $0.9 \pm 0.1 \mathrm{a}$ & $1.0 \pm 0.0 \mathrm{a}$ & $0.6 \pm 0.2 \mathrm{ab}$ & $0.0 \pm 0.0 b$ & 10.855 & 0.000 \\
\hline \multirow[t]{3}{*}{ Species diversity $\left(H^{\prime}\right)$} & Total & $0.8 \pm 0.2 \mathrm{a}$ & $0.8 \pm 0.1 \mathrm{a}$ & $0.7 \pm 0.1 \mathrm{a}$ & $0.4 \pm 0.1 \mathrm{ab}$ & $0.0 \pm 0.0 b$ & 17.142 & 0.000 \\
\hline & Lichens & $0.7 \pm 0.1 \mathrm{a}$ & $0.5 \pm 0.1 \mathrm{ab}$ & $0.3 \pm 0.1 \mathrm{abc}$ & $0.1 \pm 0.1 \mathrm{bc}$ & $0.0 \pm 0.0 c$ & 11.311 & 0.000 \\
\hline & Mosses & $0.1 \pm 0.1$ & $0.0 \pm 0.0$ & $0.0 \pm 0.0$ & $0.0 \pm 0.0$ & $0.0 \pm 0.0$ & 0.844 & 0.504 \\
\hline \multirow[t]{3}{*}{ Evenness $\left(J^{\prime}\right)$} & Total & $0.7 \pm 0.1$ & $0.8 \pm 0.0$ & $0.7 \pm 0.1$ & $0.5 \pm 0.0$ & - & 1.775 & 0.178 \\
\hline & Lichens & $0.7 \pm 0.1$ & $0.7 \pm 0.1$ & $0.7 \pm 0.2$ & $0.4 \pm 0.0$ & - & 0.561 & 0.648 \\
\hline & Mosses & $0.6 \pm 0.0$ & - & - & - & - & - & NV \\
\hline \multirow[t]{3}{*}{ Dominant index $(C)$} & Total & $0.6 \pm 0.1 \mathrm{a}$ & $0.5 \pm 0.1 \mathrm{a}$ & $0.6 \pm 0.1 \mathrm{a}$ & $0.8 \pm 0.1 \mathrm{ab}$ & $1.0 \pm 0.0 \mathrm{~b}$ & 18.560 & 0.000 \\
\hline & Lichens & $0.6 \pm 0.1 \mathrm{a}$ & $0.7 \pm 0.1 \mathrm{ab}$ & $0.8 \pm 0.1 \mathrm{ab}$ & $0.9 \pm 0.1 b$ & $0.0 \pm 0.0 c$ & 55.722 & 0.000 \\
\hline & Mosses & $0.5 \pm 0.1 \mathrm{a}$ & $0.9 \pm 0.1 \mathrm{ab}$ & $1.0 \pm 0.0 \mathrm{~b}$ & $0.6 \pm 0.2 a b$ & $0.0 \pm 0.0 c$ & 21.186 & 0.000 \\
\hline
\end{tabular}

According to Tukey's test, columns are statistically different where they do not share any letter $(P<0.05)$

$N V$ no variation in dependent variable

\section{Influences of snow melting on the formation of lichen and moss communities}

Table 5 compares the covered percentages of species the appeared in sections $0,2,4,5$, and 6 classified by snow melting time. Species with significant difference in coverage according to the snow-covered time were Andreaea regularis, crustose lichens, Placopsis contortuplicata, Usnea aurantiaco-atra, and snow algae. P. contortuplicata did not show significant differences among locations even when snow melted for a short time. For species decreased in coverage as the snow-covered time is longer, A. regularis $(0.30 \sim 2.17)$ and $P$. contortuplicata $(0.10 \sim 0.88)$ decreased smoothly while the coverage of $U$. aurantiacoatra was higher in non-snow-covered areas but it showed very lower coverage in sections snow covered for more than 2 weeks. Establishment of Usnea spp. in this area because this is not a short-term response to snow, because it requires very long period and exposing for sufficient growth. Crustose lichens were increasing as snow-covered time was longer, and it was the maximum in section 4

Table 5 Comparison of coverage of each species among vegetation types classified with snow cover duration (week)

\begin{tabular}{|c|c|c|c|c|c|c|c|}
\hline \multirow[t]{2}{*}{ Species } & \multicolumn{5}{|c|}{ Snow cover duration (week) } & \multirow[t]{2}{*}{ F ratio } & \multirow[t]{2}{*}{$P$} \\
\hline & 0 & 2 & 4 & 5 & 6 & & \\
\hline Andreaea regularis & $2.17 \pm 0.73 a$ & $1.06 \pm 0.31 b$ & $1.00 \pm 0.35 b$ & $0.30 \pm 0.12 b$ & $0.00 \pm 0.00 \mathrm{~b}$ & 5.692 & 0.001 \\
\hline Ditrichum hyalinum & $0.17 \pm 0.17$ & $0.00 \pm 0.00$ & $0.00 \pm 0.00$ & $0.00 \pm 0.00$ & $0.00 \pm 0.00$ & 0.866 & 0.491 \\
\hline Sanionia uncinata & $0.04 \pm 0.04$ & $0.00 \pm 0.00$ & $0.00 \pm 0.00$ & $0.00 \pm 0.00$ & $0.00 \pm 0.00$ & 0.866 & 0.491 \\
\hline Crustose lichens & $1.17 \pm 0.36 \mathrm{a}$ & $3.72 \pm 0.69 b$ & $4.29 \pm 0.64 b$ & $3.4 \pm 1.29 b$ & $0.00 \pm 0.00 \mathrm{a}$ & 19.392 & 0.000 \\
\hline Ochrolechia frigida & $0.33 \pm 0.25$ & $0.00 \pm 0.00$ & $0.00 \pm 0.00$ & $0.00 \pm 0.00$ & $0.00 \pm 0.00$ & 1.556 & 0.201 \\
\hline Rhizocarpon geographicum & $0.04 \pm 0.04$ & $0.00 \pm 0.00$ & $0.00 \pm 0.00$ & $0.00 \pm 0.00$ & $0.00 \pm 0.00$ & 0.866 & 0.491 \\
\hline Stereocaulon alpinum & $0.13 \pm 0.09$ & $0.00 \pm 0.00$ & $0.00 \pm 0.00$ & $0.00 \pm 0.00$ & $0.00 \pm 0.00$ & 1.681 & 0.169 \\
\hline Placopsis contortuplicata & $0.88 \pm 0.22 \mathrm{a}$ & $0.67 \pm 0.14 a$ & $0.64 \pm 0.36 \mathrm{a}$ & $0.10 \pm 0.10 a$ & $0.00 \pm 0.00 \mathrm{~b}$ & 6.809 & 0.000 \\
\hline Usnea aurantiaco-atra & $7.00 \pm 0.74 \mathrm{a}$ & $0.61 \pm 0.32 b$ & $0.14 \pm 0.09 b$ & $0.10 \pm 0.10 \mathrm{~b}$ & $0.00 \pm 0.00 \mathrm{~b}$ & 67.145 & 0.000 \\
\hline Snow algae & $0.00 \pm 0.00 \mathrm{a}$ & $0.00 \pm 0.00 \mathrm{a}$ & $0.00 \pm 0.00 \mathrm{a}$ & $1.20 \pm 1.20 \mathrm{~b}$ & $10.95 \pm 0.05 c$ & 615.473 & 0.000 \\
\hline
\end{tabular}

According to Tukey's test, columns are statistically different where they do not share any letter $(P<0.05)$ 
when snow-covered time was 4 weeks, and finally it tended to decrease. Snow algae started to increase in the location with more than 5 weeks snow covered (Table 5).

Figure 4 is a result of CCA analysis based on the data of each species' coverage and environmental factors in order to figure out how the distribution of species appeared in the investigated region is determined. In the CCA plot, distributions of species in the researched areas were broadly divided into five groups. The first one is snow algae and is located in the left of axis 1 and middle of axis 2 in the CCA plot, while the second one, crustose lichens is located in the middle of axis 1 and below of axis 2 . For third one, it is A. regularis, Stereocaulon alpinum, and $P$. contortuplicata and it was located in the right of axis 1 and below of axis 2. The fourth group is mosses and lichens over mosses, Sanionia uncinata, Ditrichum hyalinum, and S. alpinum and is located in the right of axis 1 and middle of axis 2 while the fifth one is U. aurantiacoatra and Rhizocarpon geographicum and is located in the right of axis 1 and above of axis 2 in the CCA plot (Fig. 4).

The first group, snow algae, can be distributed separately, located in valleys of southwest slope, where the ground is always snow covered. Other groups are distinguished depending on snow melting time and substrates. In the annual year's summer, snow melts for a very short time, or in a cold year, where it is always snow covered in the summer time, crustose lichens belonging to the second group only distribute. Actually, in the summer time of Barton Peninsula, degrees of snow cover are very different each year. Even in the same location in the same region, in the summer in a hot year, the land is exposed to a lot while it is always snow covered in the summer if the year is cold. Therefore, without other species, the region with crustose lichens only is limitedly exposed in regularly coming hot years not annually. This species is an important indicator because it shows the period not snow covered even if it is temporal. The third group, A. regularis, $S$. alpinum, and $P$. contortuplicata, is not in the location where snow always melts during summer but the group is distributed in middle-level location with at least snow-free area annually. They grow relatively fast and seem to be species with faster responses on climatic fluctuation. The fourth and fifth groups are dominated in the locations where snow always melts during summer, and differences of distribution between them seem to be related to moisture or water supply in the ground. The fourth group, S. uncinata, D. hyalinum and S. alpinum, preferred flat areas while the fifth group, $U$. aurantiaco-atra and $R$. geographicum, preferred large substrates for attachment and

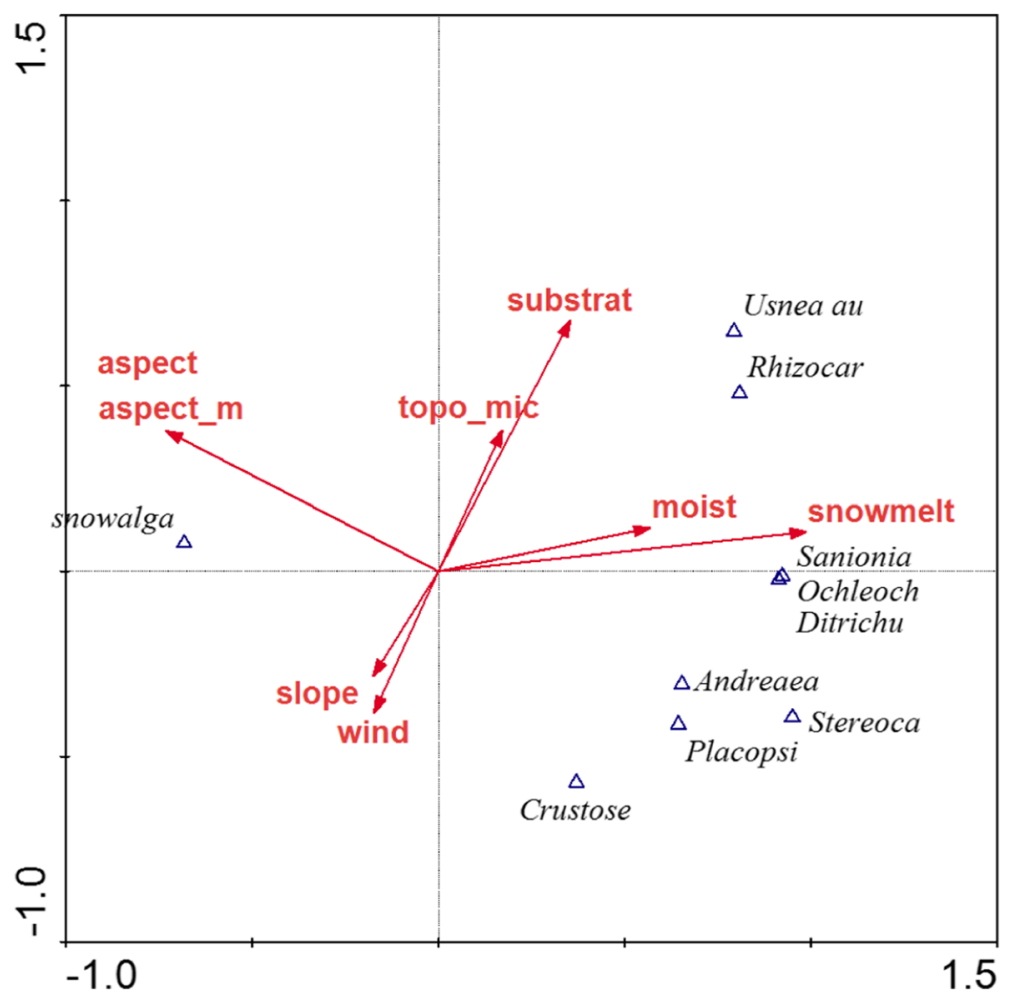

Fig. 4 CCA ordination plot of the data matrix based on the environmental and species coverage on February 18, 2015. aspect_m microaspect, topo_mic microtopography, snow melt snow cover duration, Crustose crustose lichens, Usnea au, Usnea aurantiaco-atra, Rhizocar Rhizocarpon geographicum, Sanionia Sanionia uncinata, Ochleoch Ochleochia frigida, Ditrichu Ditrichum hyalinum, Andreaea Andreaea regalis, Stereoca Stereocaulon alpinum, Placopsi Placopsis contortuplicata 
preferred long-term-exposed area with few physical damage factors by snow in order to maintain growth form. Therefore, the location settled with sufficiently sized Usnea in Barton Peninsula is the location that is exposed by snow melting during summer in a cold year regardless of climatic fluctuation.

In conclusion, changes in vegetation in small-scale regions in Barton Peninsula are gradual from the first group to the third one. But for the fourth and fifth ones, depending on substrate, surface status, and differences of water supply, vegetations were divided into different groups. That is, the final stage of vegetation succession in this research area divided into two different types, wet vegetation climax dominated by mosses and dry vegetation climax dominated by fruticose lichens, depending on the water supply and substrate.

\section{Discussion}

The environmental factors related to snow melting in the coastal lowlands in Barton Peninsula were altitude, direction, micro-topography, particle size of substrate, and water content (Table 2). Among them, factors expected to directly affect snow melting were altitude, direction, and micro-topography. Differences in locational environmental factors between snow-covered and snow-free areas were very huge, but there were no statistically significant environment gradients according to snow melting time. The reason was that the study was conducted in a very small-scale region. If the scale is bigger as middle and large sizes, distinctive environmental gradients according to snow melting can be confirmed and differences of vegetation types according to them are also very clear (Kim et al. 2007). In the maritime Antarctic region including Barton Peninsular, distribution of vegetation is largely affected by micro-topography, particle size of ground surface substrates, water contents, and snow cover (Kim et al. 2007, Garibotti et al. 2011, Kim et al. 2012, Favero-Longo et al. 2012, Choi 2015, Choi et al 2015). For lichens and mosses showing changes in coverage in the snow-covered period, there are four species: snow algae, crustose lichens, $A$. regularis, and $U$. aurantiaco-atra (Table 5). Among them, $U$. aurantiaco-atra shows very huge changes in coverage depending on snow cover and is directly affected by snow cover. A. regularis and $P$. contortuplicata decrease smoothly as snow-covered time is longer (Table 5). As snow melting time is longer, height and coverage of the entire vegetation, lichens, and mosses tended to increase clearly. There were huge differences between location where snow always melts during summer and those where snow melts temporally (Table 3 ). Compared to it, species diversity and density tended to increase gradually according to longer snow melting time. In particular, in case of lichens, the tendency was clear. However, mosses, as affected by moisture, during middle- scale snow melting time, tended to have relatively higher species density and diversity but there was no statistically significance. For dominance index, it tended to be higher in early assembly stage of community with longer snowcovered time (Table 4). These tendencies show that the snow-free locations have communities in the process of assembling not completely assembled ones. Through CCA analysis, distributions of species in the research areas were broadly classified into five groups: the first group, snow algae; second group, crustose lichens; third group, A. regularis, S. alpinum, and P. contortuplicata; fourth group, which are mosses and lichens, colonized on mosses, S. uncinata, D. hyalinum, and S. alpinum; and the fifth group, $U$. aurantiaco-atra and $R$. geographicum (Fig. 4). Their spatial distribution patterns show directional processes to assemble communities and for the formation and development of communities, from the first one to the third one. The fourth and fifth groups where the snow melts annually seem to be differentiated by differences in substrates and water supply in the locations. In the final stage of the community assembly in the study area, it is very likely to branch into the development of the lichen communities in the dry succession sere and development of moss communities in the wet succession sere according to the water supply (Kim et al. 2007, Choi et al. 2015).

In conclusion, assemblies of communities in smallscale valleys in Barton Peninsular are located in the maritime Antarctic region, like the primary succession processes according to time flow after glacier retreat, depending on water gradient by snow melting order and differences of responses of main species on environmental gradients of micro-environmental factors (Favero-Longo et al. 2012). In addition, with interaction between spatial heterogeneity of these factors and assembling processes of communities, it seems that distributions of main species in Barton Peninsula are determined. In high Arctic regions, surface stones are reported as a factor to determine patters of vegetation (Cannone and Gerdol 2003, Sedel'nikova and Sedel'nikov 2009). However, this study was conducted in a small-scale region, and gradients in particle sizes in surface stones are not distinctive. In addition, environmental gradients of locational factors according to snow melting time are not clear, either. Therefore, assembly of community and distribution of main species in the researched areas seemed to be affected by differences of responses on snow kill by snow cover and water gradients rather than differences of substrates.

Primary succession of the cryptogam community in extremely cold environment is mainly made in the Arctic ecosystem with higher latitude, and in general, for successions in these regions, directional succession without species replacement and non-direction succession dominant in polar deserts are reported. There is also 
directional-replacement succession accompanying in favorable local conditions (Jones and Henry 2003). In the research site, five species groups showing different distribution patterns were identified (Fig. 4). Kim et al. (2007) classified more than ten types of communities, using cluster analysis based on the vegetation investigation results conducted around King Sejong Station in Barton Peninsula, and made them belong to a total of four community types of the plant-sociological classification system from the previous studies. Cryptogam community types confirmed around King Sejong Station in Barton Peninsular were fruticose lichen and moss cushion sub-formation, crustose lichen sub-formation, moss carpet sub-formation, and moss hummock subformation (Kim et al. 2007). When comparing and contrasting the four species groups formed in snow-free locations in this study with these studies, group 2 dominated by crustose lichens which can belong to crustose lichen sub-formation while groups 3 and 5 can belong to fruticose lichen and moss cushion sub-formation and group 4 dominated with Sanionia which can belong to moss carpet sub-formation, respectively (Fig. 4). In snow-covered areas on Barton Peninsula, algae were dominant and then density and number of algae on the snow are determined depending on addition of $N$ and $P$ caused by animal excrements (Holdgate et al. 1967, Lewis smith 1972). As snow melts, various associations belonging to crustose lichen formation and dominated by crustose lichens are formed (Kim et al. 2007). These communities are an indicator showing how long snow has melted. Recently, newly snow-free areas because of climatic warming are naked lands. However, as snow repeatedly melts for a long time, coverage of crustose lichen is increasing. As snow melts repeatedly for a long time and the exposed time is longer in the summer, gradually, various associations belonging to fruticose lichen and moss cushion sub-formation are made and their representative is Andreaea sociation (Kim et al. 2007). There are smaller differences of moisture condition according to substrates because these associations form in snow melting and flowing areas. In this area, climax stage is formed on dried slope and ridge where snow always melts during summer. In such locational condition, Usnea-crustose lichen sociation, belonging to fruticose lichen and moss cushion sub-formation, is developed (Kim et al. 2007). In this area, it appeared very rarely but in the wet location with continuous moisture supply, Sanionia sociation belonging to moss carpet subformation with very fast growth may be formed (Kim et al. 2007). In the succession in the investigated areas, unlike the primary succession in the Arctic region, vascular plants do not participate. In addition, the area was recently glacier retreated and the ground is covered with large particle substrates which soil development is very weak. Therefore, after various lichens and mosses are settled in snow-free locations, according to differences of resistances of each species against snow and moisture, communities are assembled and developed. The order and frequency of snow melting in coastal lowland areas in Barton Peninsula depends on topography and climatic fluctuation (Choi et al. 2015).

\section{Conclusions}

In conclusion, distribution of vegetation and assembly of cryptogam communities are likely different according to the length of growth period due to snow melting time and frequency and differentiated responses of each species on physical snow at coastal region of the Barton Peninsula (Table 5). Furthermore, in order to understand the ecological response of vegetation along the Barton Peninsula in the snow melting and retreating glaciers due to climate change in the entire peninsula in a wider space than this paper study on the establishment and development of vegetation it is required.

\section{Abbreviations \\ ANOVA: Analysis of variance; B.C.: Before Christ; CCA: Canonical correlation analysis}

\section{Acknowledgements \\ We thank Eunsuk Kim, Jae Eun So, and Young-June Yoon for sharing their fieldwork. We also thank the 28th Korean Antarctic overwintering members for their field assistance. This research was funded by the Korea Polar Research Institute (PE15020)}

\section{Availability of data and materials}

Data sharing not applicable to this article as no datasets were generated or analyzed during the current study. Please contact author for data requests.

\section{Authors' contributions}

SCK conceived of the study, participated in the design of the study, performed the statistical analysis, and wrote this article. JSK and BRH participated in the design of study and participated in the data analysis. SGH and JHK participated in the design of the study. KSL conceived of the study, participated in its design and coordination, and helped to draft the manuscript. All authors read and approved the final manuscript.

\section{Competing interests}

The authors declare that they have no competing interests.

\section{Consent for publication}

Not applicable.

\section{Ethics approval and consent to participate} Not applicable.

\section{Author details}

'Department of Biology, Gangneung-Wonju National University, Gangneung 25457, South Korea. ${ }^{2}$ Division of Polar Life Sciences, Korea Polar Research Institute, Incheon 21990, South Korea.

Received: 24 March 2016 Accepted: 1 July 2016

Published online: 24 October 2016

\section{References}

Bisigato, A. J., Villagra, P. E., Ares, J. O., \& Rossi, B. E. (2009). Vegetation heterogeneity in Monte Desert ecosystems: a multi-scale approach liking patterns and processes. Journal of Arid Environments, 73, 182-191. 
Björck, S., Sandgren, P., \& Zale, R. (1991). Late Holocene tephrochronology of the northern Antarctic Peninsula. Q Res, 36, 322-328.

Cannone, N., \& Gerdol, R. (2003). Vegetation as an ecological indicator of surface instability in rock glaciers. Arctic, Antarctic, and Alpine Research, 35, 384-390.

Choi, S. H. (2015). Influence of microenvironment on the spatial distribution of Himantormia lugubris (Parmeliaceae). MS Thesis. Gangneung-Wonju National University, Gangneung, Korea.

Choi, S. H., Kim, S. C., Hong, S. G., \& Lee, K. S. (2015). Influence of microenvironment on the spatial distribution of Himantormia lugubris (Parmeliaceae) in ASPA No. 171, maritime Antarctic. J Ecol Environ, 38, 493-503.

Chung, H. S., Lee, B. Y., Chang, S. K., Kim, J. H., \& Kim, Y. D. (2004). Ice cliff retreat and sea-ice formation observed around King Sejong Station in King George Island, West Antarctica. Ocean Polar Res, 26, 1-10.

Convey, P., Bindschadler, R. A., di Prisco, G., Fahrbach, E., Gutt, J., Hodgson, D. A., Mayewski, P., Summerhayes, C. P., \& Turner, J. (2009). Antarctic climate change and the environment. Antarctic Science, 21, 541-563.

Convey, P. (2010). Terrestrial diversity in Antarctica-recent advances and future challenges. Polar Science, 4, 135-147.

Crawley, M. J., \& Harral, J. E. (2001). Scale dependence in plant biodiversity. Science, 291, 864-868.

Favero-Longo, S. E., Worland, M. R., Convey, P., Lewis Smith, R. I., Piervittori, R., Guglielmin, M., \& Connone, N. (2012). Primary succession of lichen and bryophyte communities following glacial recession on Signy Island South Orkney Islands, Maritime Antarctic. Antarctic Science, 24, 323-336.

Garibotti, I. A., Pissolitoi, C. I., \& Villalba, R. (2011). Spatiotemporal pattern of primary succession in relation to meso-topographic gradients on recently deglaciated terrains in the Patagonian Andes. Arctic, Antarctic, and Alpine Research, 43, 555-567.

Gillson, L. (2004). Evidence of hierarchical path dynamics in an East African Savanna. Landscape Ecol, 19, 883-894.

Grimm, N. B., Chapin, F. S., Bierwagen, B., Gonzalez, P., Groffman, P. M., Luo, Y., Melton, F., Nadelhoffer, K., Pairis, A., Raymond, P. A., Schime, J., \& Williamson, C. E. (2013). The imapacts of climate change on ecosystem structure and function. Frontiers in Ecology and the Environments, 11, 474-482.

Holdgate, M. W., Allen, S. E., \& Chambers, M. J. G. (1967). A preliminary investigation of the soils of Signy Island, South Orkney Islands. British Antarctic Survey Bulletin, No., 12, 53-71.

Jones, G. A., \& Henry, G. H. R. (2003). Primary plant succession on recently deglaciated terrain in the Canadian High Arctic. Journal of Biogeography, 30, 277-296.

Kennedy, A. D. (1995). Antarctic terrestrial ecosystem response to global environmental change. Annual Review of Ecology and Systematics, 26, 683-704.

Kim, J. H., Ahn, I. Y., Lee, K. S., Chung, H. S., \& Choi, H. G. (2007). Vegetation of Barton Peninsula in the neighbourhood of King Sejong Station (King George Island, maritime Antarctic). Polar Biology, 30, 903-916.

Kim, S. C., Kim, J. H., Kim, E. H., Ahn, I. Y., Hong, S. G., \& Lee, K. S. (2012). Distributions of lichens and mosses with micro-spatial heterogeneity in the King George Island located in the Maritime Antarctic. In Abstract book of the $55^{\text {th }}$ Symposium of the International Association for Vegetation Science (p. 210).

Kim, S. C., Kim, J. S., Kim, J. H., Yoon, Y. J., Ahn, I. Y., Hong, S. G., \& Lee, K. S. (2013). Comparison on spatial distribution of species diversity for lichens and mosses at multiple scales in King George Island, Maritime Antarctic. In Abstract book of the $68^{\text {th }}$ Annual Meeting of the Korean Association of Biological Sciences (p. 175).

Korea's Ministry of Environment. (2014). Management and monitoring on Antarctic Specially Protected Area (IV). Sejong: Korea's Ministry of Environment.

Krohne, D. T. (2001). General ecology (2nd ed.). Belmont: Brooke-Cole.

Lee BY, Won Y, Oh SN. 1997. Meteorological characteristics at King Sejong Station, Antarctica (1988-1996). Report BSPE 97604-00-1020-7, (pp 571-599). Ansan, Korea: Korea Ocean Research and Development Institute.

Lewis Smith, R. I. (1972). Vegetation of the South Orkney Islands with particular reference to Signy Island. British Antarctic survey scientific reports, No. 68.

Lewis Smith, R. I. (1984). Terrestrial biology of the Antarctic and sub-Antarctic. In R. M. Laws (Ed.), Antarctic ecology (pp. 61-162). London: Academic Press.

Lewis Smith, R. I. (1990). Signy Island as a paradigm of biological and environmental change in Antarctic terrestrial ecosystems. In K. R. Kerry \& G. Hempel (Eds.), Antarctic ecosystems, ecological change and conservation (pp. 32-50). Berlin: Springer-Verlag.
Longton, R. E. (1988). The biology of polar bryophytes and lichens (p. 391). Cambridge: Cambridge University Press.

Olsen, E. R., Ramsey, R. D., \& Winn, D. S. (1993). A modified dimension as a measure of landscape diversity. Photogrammetric engineering and remote sensing, 59, 1517-1520.

Oppenheimer, M. (1998). Global warming and the stability of the West Antarctic Ice Sheet. Nature, 393, 325-332.

Parnikoza, I., Dykyy, I., Ivanets, V., Kozeretska, I., Kunakh, V., Rozhok, A., Ochyra, R., \& Convey, P. (2012). Use of Deschampsia antarctica for nest building by the kelp gull in the Argentine Island area (Maritime Antarctica) and its possible role in plant dispersal. Polar Biology, 35, 1753-1758.

Pielou, E. C. (1969). An introduction to mathematical ecology (p. 165). New York: Wiely-Interspecies.

Reynolds, J. F., \& Wu, J. (1999). Do landscape structural and functional units exist? In J. L. Tenhunen \& P. Kabat (Eds.), Integrating hydrology, ecosystem dynamics, and biogeochemistry in complex landscapes (pp. 273-296). Berlin: John Wiley \& Sons.

Sedel'nikova, N. V., \& Sedel'nikov, V. P. (2009). The role of lichens in highmountain phytocenosis of Siberia. Contemporary Problems in Ecology, 2, 586-592.

Shin, J. I., Kim, H. C., \& Hong, S. G. (2014). Vegetation abundance on the Barton Peninsula, Antarctica: estimation from high-resolution satellite images. Polar Biology, 37, 1579-1588.

Simpson, E. H. (1949). Measurement of diversity. Nature, 163, 688.

Tang, C. Q., Chiou, C. R., Lin, C. T., Lin, J. R., Hsieh, C. F., Tang, J. W., Su, W. H., \& Hou, H. (2013). Plant diversity patterns in subtropical evergreen broad-leaved forests of Yunnan and Taiwan. Ecological Research, 28, 81-92.

Ter Braak, C. J. F., \& Šmilauer, P. (2002). CANOCO reference manual and CanoDraw for Windows user's guide: software for canonical community ordination (version 4.5) (p. 500). Ithaca: Microcomputer Power.

Tilman, D., \& Pacala, S. (1993). The maintenance of species richness in plant communities. In R. E. Ricklefs \& D. Schulter (Eds.), Species diversity in ecological communities (pp. 13-25). Chicago: University of Chicago Press.

Turner, J., Bindschadler, R., Convey, P., di Prisco, G., Fahrbach, E., Gutt, J., Hodgson, D., Mayewski, P., \& Summerhayes, C. (2009). Antarctic climate change and the environment. Cambridge: Scientific Committee on Antarctic Research.

Yoon, H. I., Park, B. K., Kim, Y., \& Kim, D. (2000). Glaciomarine sedimentation and its paleoceanographic implications along the fjord margins in the South Shetland Islands, Antarctica during the last 6000 years. Palaeogeography Palaeoclimatology Palaeoecology, 157, 189-211.

\section{Submit your next manuscript to BioMed Central and we will help you at every step:}

- We accept pre-submission inquiries

- Our selector tool helps you to find the most relevant journal

- We provide round the clock customer support

- Convenient online submission

- Thorough peer review

- Inclusion in PubMed and all major indexing services

- Maximum visibility for your research

Submit your manuscript at www.biomedcentral.com/submit
) Biomed Central 